\title{
Components of driving competency measurement in the elderly: A scoping review
}

\author{
Saiedeh Bahrampouri ${ }^{1}$, Hamid Reza Khankeh*1 $\mathbb{D}$, Seyed Ali Hosseini ${ }^{1}$, Mohammadreza Mehmandar ${ }^{2}$, Abbas Ebadi $^{3,4}$ \\ Received: 5 Mar 2020 \\ Published: 5 Jan 2021
}

\section{Abstract}

Background: Iran will face the "aging Tsunami" phenomenon by the 2040s. Therefore, paying attention to the elderly's driving to maintain and promote their independence and quality of life on the one hand and paying attention to the dangers of driving by the elderly for road safety will be important. The purpose of this research was to determine the components of driving competency in the elderly.

Methods: The research has employed a scoping review. To this end, searches of scientific databases were conducted using keywords between 1990 and 2019. The process of selecting the documentation was-based on the PRISMA chart.

Results: In the first phase, 2769 records were found, and finally, 37 records met the inclusion criteria set for this study. The results indicated that 18 components were extracted that were classified into seven main categories including cognitive, sensory, motor, mental functions, and medications, diseases, and driving history.

Conclusion: Sensory, motor, and cognitive abilities are the most important components of elderly safe driving. Therefore, as age increases, chronic disease, multiple drug use, and subsequent problems increase. This can affect the ability to drive safely and can cause traffic injuries. Therefore, it is recommended to use the results of this research to design a suitable tool and model for assessing driving competency in the elderly.

Keywords: Automobile driver examinations, Aged, Automobile driving, Licensure, Traffic crashes, Geriatric assessment, Driving competency, Safe driving, Elderly

Conflicts of Interest: None declared

Funding: None

*This work has been published under CC BY-NC-SA 1.0 license

Copyright $\odot$ Iran University of Medical Sciences

Cite this article as: Bahrampouri S, Khankeh HR, Hosseini SA, Mehmandar M, Ebadi A. Components of driving competency measurement in the elderly: A scoping review. Med J Islam Repub Iran. 2021 (5 Jan);35:2. https://doi.org/10.47176/mjiri.35.2

\section{Introduction}

Increasing life expectancy and health promotion has led to an increase in the population of people over 60 years old, the so-called "Aging Tsunami" (1). A quick look at the growing trend of the elderly population in Iran and comparing it with the selected countries in Figure 1 indi-

Corresponding author: Dr Hamid Reza Khankeh, hamid.khankeh@ki.se

1. Health in Emergency and Disaster Research Center, University of Social Welfare and Rehabilitation Sciences, Tehran, Iran

2. Police University, NAJA Traffic Police, Tehran, Iran

3. Behavioral Sciences Research Center, Life Style, Baqiyatallah University of Medical Sciences, Tehran, Iran

4. Nursing Faculty, Baqiyatallah University of Medical Sciences, Tehran, Iran cates that the trend in Iran is growing faster.

In the meantime, maintaining the independence of the elderly to enhance social participation and quality of life is crucial (3). In fact, driving is a symbol of self-esteem and the freedom of the elderly (4).

\section{$\uparrow$ What is "already known" in this topic:}

Decrease in natural abilities and diseases of old age affect driving performance. Since different components affect driving, identifying them can help to accurately assess the driving skills of the elderly. Appropriate assessment of the driving license of the elderly at the time of renewal of the license can improve the safety of road users by reducing driving errors and accidents.

\section{$\rightarrow$ What this article adds:}

This study identified and classified the main effective components for the driving license of the elderly. The findings of the study have provided the necessary context for the preparation of native tools for use by the police NAJA when renewing the driver's license for the elderly. 


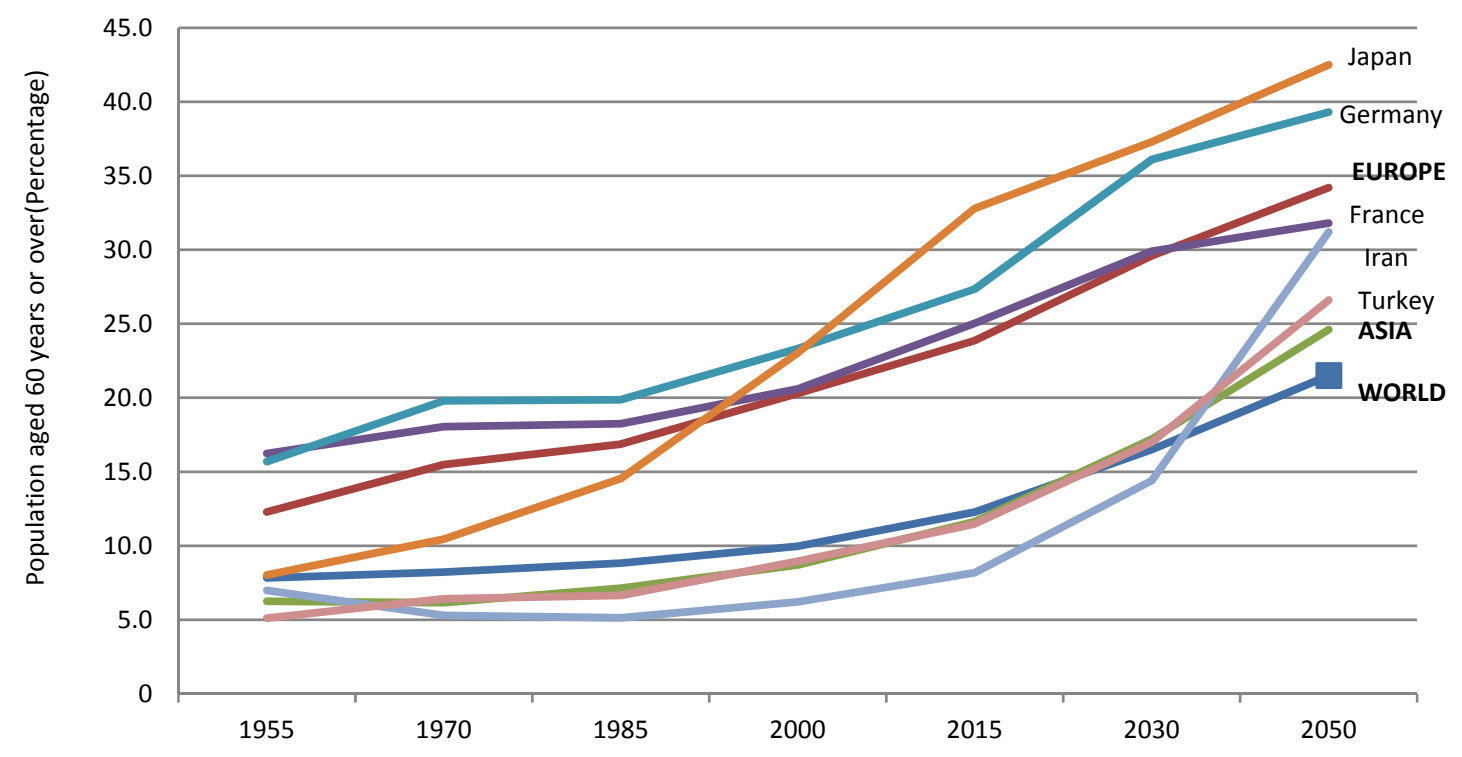

Fig. 1. The trend of elderly population growth in Iran and the world (2)

Driving is a complex activity that requires multiple tasks at the same time (3). Driving requires seeing and hearing clearly, paying attention to other cars, signs and alarms, and pedestrians, and responding quickly and appropriately react to events that drivers typically perform regularly using their perceptual, cognitive, and motor abilities (3).

The number of elder drivers has increased coincided with increasing the number of elderly; so that more than 40 million people in their 60 s and over in the United States had a valid driver's license in 2015, according to CDC (Centers for Disease Control and Prevention). That number has increased as much as 50\% since 1999 (5). Elderly driving is associated with an increased risk for drivers and other road users. Results from various statistics indicate that the death rate of older drivers (generally more than 70 years) is higher than drivers of other age groups $(6,7)$. According to the findings of the Evans study, the death rate of drivers at the age of 85 and older was 9 times higher than drivers at the age of 25 to 69 years old ( 7$)$.

However, the primary cause of elderly car accidents is their age limitations rather than careless behavior and irresponsibility (8). Although the number of accidents at these ages is higher than other groups, it is important to note that the capabilities of all older drivers do not necessarily decrease in a certain proportion. On the other hand, higher rates of depression, isolation, reduced self-esteem, decreased physical and social performance, increased mortality, and decreased quality of life of elderly people without a renewed driver's license $(9,10)$. The results of a study in Japan showed that the death rate from traffic accidents in this age group decreased to less than one second in the same period with the use of appropriate measures given the 1.3 times increase in the number of drivers over 75 years from 2003 to 2013 (11).

Therefore, it is necessary to establish appropriate criteria for assessing the driving competence of this age group to ensure both the safety of road users and the preservation of independence and health of the elderly. Examination of the extension of driving license in different countries shows that the criteria for measuring eligibility for driving in the world do not follow the same pattern (12).

Since identifying factors affecting age-related driving is considered as a key strategy to reduce the risk of elderly driving (13), this study was designed and conducted to determine the main components that determine driving eligibility of the elderly.

\section{Methods}

The present study is a scoping review. The advanced search was conducted at PubMed, Scopus, ProQuest, Web of Science, google scholar databases using keywords like the battery, model, screening tool, guideline, Predictor factors, older / elder driver, and proper communication words including OR, AND (Table 1).

The inclusion criteria include English language, original and review studies and other documentation including tools and guidelines and exclusion criteria include studies specifically targeting elderly people with a particular illness or disability such as stroke web-based tools, do not access to the full articles, studies that used simulation as a screening tool or study outcome.

Searching for the records was conducted from 1990 to August 2019, and all studies with defined criteria were reviewed. The research team also searched for gray literature through library resources search and google search to 
Table 1. Search strategy

\begin{tabular}{|c|c|c|}
\hline Database & Search strategy & $\mathrm{N}$ \\
\hline PUBMED & $\begin{array}{l}(((((\text { Battery[Title/Abstract]) OR Model[Title/Abstract]) OR Guideline[Title/Abstract]) OR Predictor } \\
\text { factors[Title/Abstract]) OR Screening Tool[Title/Abstract]) OR Multivariate Analysis[Title/Abstract]) } \\
\text { AND ((older driver*[Title/Abstract]) OR elder driver*[Title/Abstract]) }\end{array}$ & 159 \\
\hline Scopus & $\begin{array}{l}\text { AND ((older driver*[Title/Abstract]) OR elder driver*[Title/Abstract]) } \\
\text { ( ( TITLE-ABS-KEY ("older driver") OR TITLE-ABS-KEY ("elder driver") ) ) AND ( ( TITLE- } \\
\text { ABS-KEY ( battery ) OR TITLE-ABS-KEY ( model ) OR TITLE-ABS-KEY ( guideline ) OR TITLE- } \\
\text { ABS-KEY ("Predictor factor") OR TITLE-ABS-KEY ("Screening Tool") OR TITLE-ABS- } \\
\text { KEY ("Multivariate Analysis") ) ) }\end{array}$ & 572 \\
\hline ProQuest & $\begin{array}{l}\text { ((ab(older driver) OR ab(elder driver)) AND (ab(multivariate analysis) OR ab(battery) OR ab(screening } \\
\text { tool) OR ab(Predictor factor) OR ab(model) OR ab(guideline)) ) OR ((ti(multivariate analysis) OR } \\
\text { ti(screening tool) OR ti(Predictor factor) OR ti(guideline) OR ti(model) OR ti(battery)) AND (ti(older } \\
\text { driver) OR ti(elder driver))) }\end{array}$ & 1779 \\
\hline $\begin{array}{l}\text { Web of } \\
\text { Science }\end{array}$ & $\begin{array}{l}(\mathrm{TI}=(\text { battery }) \text { OR } \mathrm{TI}=(\text { model }) \text { OR TI }=(\text { guideline }) \text { OR } \mathrm{TI}=(\text { Predictor factor }) \text { OR } \mathrm{TI}=(\text { Screening Tool }) \text { OR } \\
\mathrm{TI}=(\text { Multivariate Analysis })) \text { AND (TS }=(\text { older driver* }) \text { OR TS }=(\text { elder driver* }))\end{array}$ & 237 \\
\hline $\begin{array}{l}\text { Google } \\
\text { scholar }\end{array}$ & battery, model, screening tool, guideline, Predictor factors, Multivariate Analysis, older driver, elder driver & 22 \\
\hline
\end{tabular}

increase the search sensitivity.

The process of selecting the documentation for this study, according to the PRISMA chart, is illustrated in Figure 2.

Two authors (S.B, A.E) independently did all steps such as search, title/abstract screening, and full-text assessment for eligibilities. Data extraction was done by self-made form, based on the aim of the research, that includes author, year, location of study, title, abstract, source, name and type of production, outcome measurement, components, and references. Two authors (S.B, A.E) independently charted the data and continuously updated the data charting form in an iterative process.

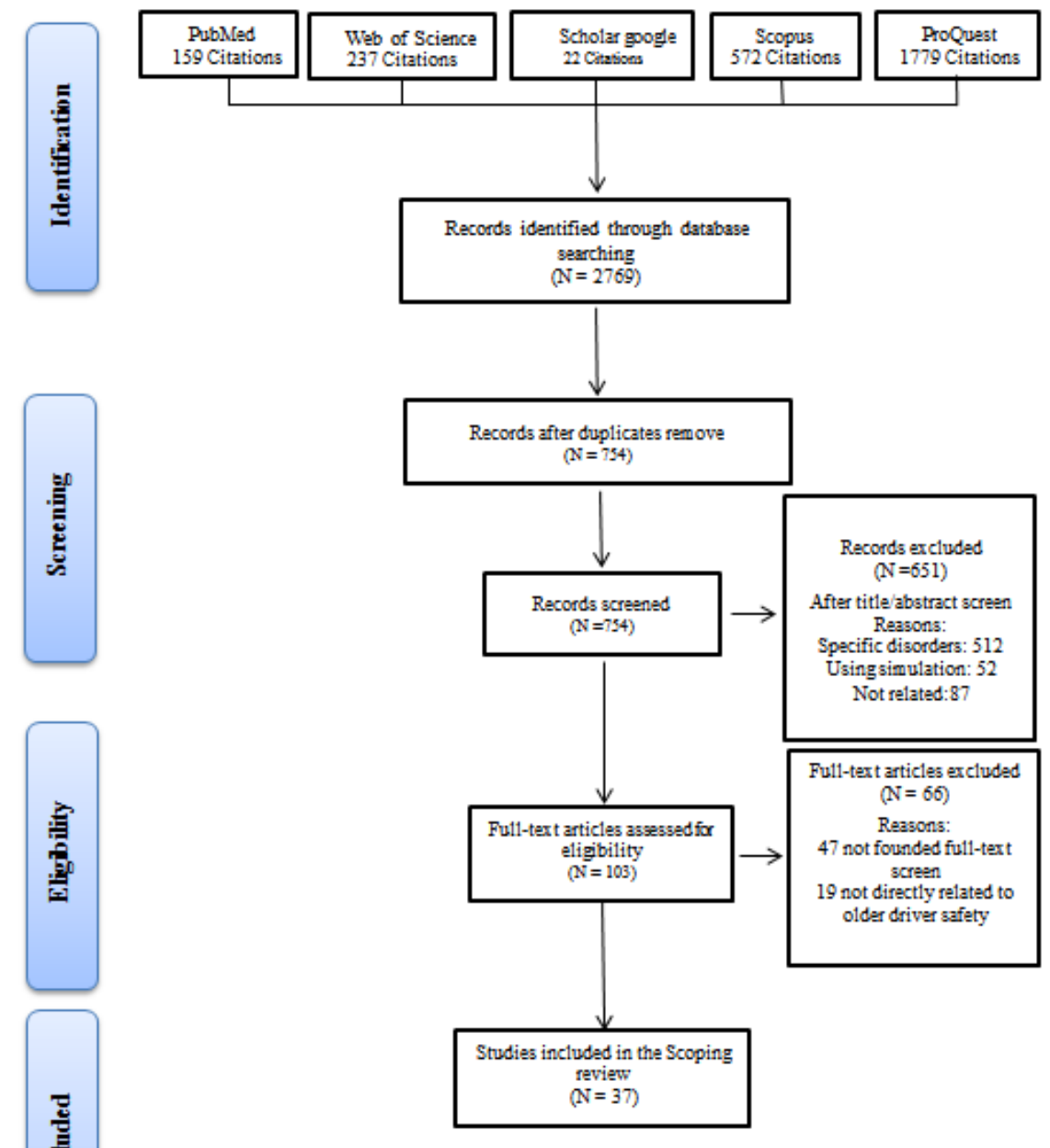




\section{Results}

Descriptive findings on the type of output of the selected studies are presented in Table 2.

Appendix summarizes the findings of the selected studies.

Table 3 examines the types and frequencies of components in the selected documentation.

The main components and dimensions of each of the components extracted in this study are shown in Table 4.

\section{Discussion}

The findings of this study were classified into seven main groups, including cognitive, sensory, motor, Emotion$\mathrm{al} /$ Mental and medications, diseases, and driving history.

Driving as a complex task requires efficient and appropriate use of various sensory, motor, and cognitive functions (21). The driver must be able to respond to unusual and unexpected events while driving. On average, each driver needs 20 decisions to travel each mile, and it takes approximately half a second for a proper response to avoid a potential accident (50). Since integration in the functions required to drive has naturally diminished with age, the consequences of driving-related abilities also occur in addition to diseases of old age and medications used to relieve and treat them.

In this study, the health-related abilities required for safe driving in the elderly were examined. The following are the main extracted concepts:

Sensory Functions: Driving is a vision-driven task because vision provides about $90 \%$ of the information needed for safe driving (51). Visual perception refers to the brain's capacity to recognize and interpret visual stimuli,

\begin{tabular}{lccc}
\multicolumn{4}{l}{ Table 2. Frequency of study outputs in selected records } \\
\hline No & Type of study's outputs & $\mathrm{N}$ & $\%$ \\
\hline 1 & Battery & 21 & 31.6 \\
2 & Model & 9 & 23.7 \\
3 & Guideline & 6 & 15.8 \\
4 & Screening Tool & 6 & 15.8 \\
5 & Predictor factors & 5 & 13.1 \\
Total & & 37 & 100 \\
\hline
\end{tabular}

\begin{tabular}{lccc} 
Table 3. Extracted components of this review & & \\
\hline No & Components & $\mathrm{F}$ & $\%$ \\
\hline 1 & Cognitive Function & 31 & 22.3 \\
2 & Sensory function & 27 & 19.4 \\
3 & medical conditions \& History & 15 & 10.8 \\
4 & Motor & 10 & 7.2 \\
5 & Physical functions & 10 & 7.2 \\
6 & Driving Experience \&Behaviors & 9 & 6.5 \\
7 & Medication use & 8 & 5.8 \\
8 & Mental \& Emotional Functions & 6 & 4.3 \\
9 & Review Of Systems \& Initial & 6 & 4.3 \\
& Screen & & \\
10 & Functional Status & 3 & 2.2 \\
11 & Perceptual functions & 3 & 2.2 \\
12 & Crash History & 2 & 1.4 \\
13 & Family Concerns & 2 & 1.4 \\
14 & On-Road Driving & 2 & 1.4 \\
15 & Psychomotor functions & 2 & 1.4 \\
16 & Demographics & 1 & 0.7 \\
17 & Ethanol use & 1 & 0.7 \\
18 & visual- cognitive ability & 1 & 0.7 \\
Total & & 139 & 100 \\
\hline
\end{tabular}

which constitute the visual function of individuals together with visual processing (which is part of cognitive ability) (52).

Typically, the visual condition deteriorates with age, and the speed of visual processing becomes slower $(3,53)$. Increasing age is associated with structural changes in eyes that can lead to decreased visual acuity, contrast sensitivity, visual field, and increased glare. However, problems such as visual acuity can be corrected by wearing glasses, but others are not correctable and increase the risk of driving, especially at night (53).

Elderly eyes need more light and time to adapt to luminous changes (3). Visual clarity decreases at sunrise, sunset, and at night. The sensitivity of the eyes to high lights, especially the headlights of front cars and street lights, increases the difficulty of seeing people, objects, and motions outside the straight line of vision (3).

However, most vision problems are a combination of eye building problems and cognitive problems, especially the speed of processing, visual processing, and attention shift (53).

The prevalence of eye diseases such as cataracts, retinopathy, glaucoma, and macular degeneration also increases with age. These diseases not only reduce vision but also reduce the depth of vision and visual field that are associated with reduced ability to estimate distance and speed (50). The most common age-related eye diseases are cataracts and glaucoma $(53,54)$.

The hearing also decreases sharply with age, but it generally does not have a significant effect on driving quality (53). However, severe hearing problems can lead to disregard for important sounds and alarms while driving and increase the risk of traffic accidents (3).

Cognition Functions: Naturally, some cognitive abilities such as conceptual reasoning, memory, and processing speed decrease with age (55). The cognitive abilities of the driver are closely related to the driving situation, and many of its dimensions are essential for safe driving (3).

Age-related cognitive problems are the cause of various types of human errors while driving (56). Therefore, special attention has been paid to the assessment of different cognitive dimensions to assess the driving ability of the elderly.

Some of the important aspects to consider in the cognitive assessment of drivers include attention, reaction time, multitasking, visual processing, short-term and working memory, executive function, and visual search $(33,50)$. Reducing any of the cognitive areas needed can have a negative impact on driving abilities that require decisionmaking and rapid response based on instantaneous situations (33).

In general, executive functions have a wide range of cognitive processes and behavioral competencies, including verbal reasoning, planning, ability to sustain attention, problem-solving, resistance to interference, cognitive flexibility, use of feedback, sequencing, multitasking, the ability to deal with novelty, etc. (57). Another study examines the most important aspects of executive functions for driving are impulse control/inhibition, working memory, deci- 
Table 4. Main dimensions of extracted components

\begin{tabular}{|c|c|c|c|c|}
\hline Cognition Function & Sensory Function & Physical Function & Review Of Systems & Medication Status \& Drug Abuse \\
\hline - Attention & - Vision & - Balance & - Chronic Medical Conditions & - Benzodiazepines \\
\hline ○ Visual Attention & $\circ$ Vision acuity & - Range Of Motion & - Cardiovascular conditions & - Narcotics \\
\hline ○ Divided attention & ○ Contrast sensitivity & $\begin{array}{l}\text { - Functional range of mo- } \\
\text { tion }\end{array}$ & - Diabetes mellitus & - Antihistamines \\
\hline o Selective Attention & o Peripheral vision & $\begin{array}{l}\text { - Gross mobility and bal- } \\
\text { ance }\end{array}$ & - Eye disease & - Sedatives and hypnotics \\
\hline - Memory & $\circ$ Visual fields & - Coordination & - Glaucoma & $\begin{array}{l}\text { - Anticholinergic medications such } \\
\text { as }\end{array}$ \\
\hline o Short term memory & ○ Colour vision & - Flexibility and speed & - Diabetic retinopathy & ○ Tricyclic antidepressants \\
\hline $\begin{array}{l}\text { o Delayed short term } \\
\text { memory }\end{array}$ & • Hearing loss & - Physical flexibility & - Age-related macular degeneration & ○ Antipsychotics, oxybutynin \\
\hline$\circ$ Visual memory & - Pain & - Upper body & - Neurological disease & ○ Dimenhydrinate \\
\hline ○ Verbal memory & - Perception & - Shoulder & - Non-Alzheimers dementia & \\
\hline ○ Working Memory & - Depth perception & $\begin{array}{l}\text { - Limb proprioception and } \\
\text { kinesthesia }\end{array}$ & - Dementia & - Alzheimer's disease agents \\
\hline - Visual perception & & - Lower body stiffness & - Stroke & - Parkinson's disease agents \\
\hline - Visuoconstruction & & $\begin{array}{l}\text { - Upper/Lower Body Mus- } \\
\text { cle Strength/tone }\end{array}$ & - Parkinson disease & - Ethanol use \\
\hline - Visual Closure & & $\begin{array}{l}\text { - Upper Body Maximum } \\
\text { Torque (left \& right) }\end{array}$ & - Cervical arthritis & \\
\hline - Visual neglect & Mental Status & $\begin{array}{l}\text { - Upper Body Initial Reac- } \\
\text { tion Time }\end{array}$ & - Spinal stenosis & Driving Status \\
\hline - Visual search & - Mental Status & $\begin{array}{l}\text { - Hand coordination and } \\
\text { dexterity }\end{array}$ & - Musculoskeletal disease & - Recent Crashes \\
\hline $\begin{array}{l}\text { - Visualization of Miss- } \\
\text { ing Information }\end{array}$ & - Mental flexibility & - Endurance & - Arthritis & $\begin{array}{l}\text { o Driving incidents or changes in } \\
\text { the past } 5 \text { years }\end{array}$ \\
\hline - Visuospatial ability & $\begin{array}{l}\text { - Physical and mental well- } \\
\text { being }\end{array}$ & - Grip strength & - Bone and joint problems & $\begin{array}{l}\circ \text { MVCs in past year to which } \\
\text { police were called }\end{array}$ \\
\hline - Visual tracking & $\begin{array}{l}\text { - Little interest or pleasure } \\
\text { in things normally enjoyed }\end{array}$ & - Finger flexion & - Specified hip/knee disorders & - In-car experiences \\
\hline - Field of View & - Mental Status & - Fatigue & - Effects of polio & $\begin{array}{l}\text { ○ A self-reported measure of driv- } \\
\text { ing exposure }\end{array}$ \\
\hline - Motion perception & & - Perceptual speed & - Mental disease & $\begin{array}{l}\circ \text { Driver self-assessment from safe } \\
\text { driving }\end{array}$ \\
\hline - Motion detection & & - Motor function & $\begin{array}{l}\text { - Recent decline in ability to man- } \\
\text { age medications }\end{array}$ & $\begin{array}{l}\text { o Limitation in driving or stop } \\
\text { driving in past year }\end{array}$ \\
\hline - Executive function & & $\begin{array}{l}\text { - Use of a locomotion } \\
\text { appliance }\end{array}$ & - Decline in general daily decisions & - Knowledge of road signs \\
\hline - Reaction time & & $\begin{array}{l}\text { - Receiving help in trans- } \\
\text { portation }\end{array}$ & - Psychiatric conditions & $\begin{array}{l}\text { - Speed of driving compared to the } \\
\text { general flow of traffic }\end{array}$ \\
\hline - Speed of processing & & - Having an unsteady gait & • Delirium & - Driving behaviors \\
\hline - Information processing & & & - Depression & $\begin{array}{l}\text { - Drive in raining During the past } 3 \\
\text { months }\end{array}$ \\
\hline - Abstraction & & & - Other disorders & \\
\hline - Orientation & & & - Sleep disorders & \\
\hline - Insight & & & - Diarrhea & \\
\hline - Concentration & & & - Syncope or presyncope & \\
\hline - Sentence repetition & & & - Hypoglycemia & \\
\hline - Block design & & & - Hyperglycemia & \\
\hline - Comprehension & & & - Orthostatic systolic blood pressure & \\
\hline
\end{tabular}

sion making/judgment, cognitive flexibility, expresses self-awareness /insight and planning (58).

Information processing and reaction time slow down with age, and attention span may be shorter (3). It gets difficult to do two things at once. As a result, the elderly may experience a feeling of overwhelming pressure, especially by signs, warnings, pedestrians, or other vehicles at intersections (3). Attention and multitasking decrease with age (approximately in the fifth decade of life) in healthy individuals (50).

Dementia and mild cognitive impairment (MCI) are the most common diseases that cause cognitive impairment in older drivers. Drivers with dementia experience traffic accidents 2.5 to 5 times more than those without dementia (59). It is worth noting that every elderly person with mild cognitive impairment or early stages of dementia does not necessarily have a high risk of driving, and any elderly without dementia definitely do not have the necessary driving competencies (50).

Motor Functions: Motor functions play an important role in safe driving. Age-related changes in the motor system can affect a person's ability to drive and move. Motor skills such as muscle strength, endurance, and flexibility are essential for vehicle control (19). Muscle strength decreases with age by about $3 \%$ each year after the age of 70 years old (50).

Motor problems affect gait and balance, motor sequencing, sensorimotor adaptation, and motor control by aging (50). Any medical problem that affects the hands, feet, neck, and waist can affect the fitness needed to drive and can result in the urgency of maneuvering to rotate the head, steering wheel, or extend braking time (3).

Postural balance, muscle strength, and cognition are also associated with braking time while driving (53). Elderly joints may be deflected or may have difficulty walking, and movement also decreases with age and sometimes due to pain from age-related diseases such as osteoarthritis $(50,60)$. Motor coordination and dexterity, Complex and fine-grained movements also decrease with age $(53,61)$.

In addition, Morgan et al. (2018) introduced important 
driving dimensions for examining older drivers as a history of falls and gait impairment and functional impairment in ADLs or IADLs (50).

Emotional/Mental Functions: The personalities and attitudes of older drivers have a significant impact on risky driving reporting and traffic accidents (59). Many psychological factors can affect a person's ability to drive, one of which is the loss of self-esteem in driving as a result of changes in vision, physical strength, and cognition (62).

Emotional factors, such as passive experiences like anxiety or fear of losing function, can also affect driving competence (33). Taylor's study illustrates that $17-30 \%$ of drivers experience driving anxiety (63). Although emotions and emotional distress factors do not directly affect driving function, they can affect the cognitive abilities required for safe driving and decision-making and may pose a risk to driving (64).

One of the biggest concerns in this area is a decrease in consciousness or arousal. The driver's level of arousal is related to his or her level of alertness on the road, which can be reduced by the lack of sleep, fatigue, and ethanol or drug abuse (65). Anxiety and irritation can manifest as aggressive driving, while depression and mental disorders can lead to distraction and inattention while driving. The results of previous studies show that $10-35 \%$ of drivers were either emotionally upset or stressed during an accident (66).

Diseases: Some chronic age-related medical problems such as arthritis, eye disease, heart disease, arterial hypertension, diabetes, and dementia can affect the ability to drive $(9,67)$.

The effects of functional problems while driving may be due to the use of medications needed to treat one, more concomitant diseases or problems caused by pain and functional limitations associated with the disease.

Some age-related diseases such as osteoarthritis, deconditioning, extrapyramidal disorders, and brain injury (such as stroke) can decrease motor abilities. Time and distance judgments can be impaired by fatigue, neurological disorders (such as Alzheimer's disease), and visual impairments (65).

The findings of Turrado's study of GAZEL cohort data (2020) indicate that diseases such as angina, coronary disease, myocardial infarction, stroke, nephritic colic, urinary stones, and Glaucoma were associated with an increased risk of traffic accidents (68). Morgan considers peripheral neuropathy, recurrent hypoglycemia, seizure, delirium, syncope or pre-syncope, vertigo, orthostatic hypotension, stroke or TIA, visual impairment despite the correction, and neurodegenerative diseases as the most important driving disorders of the elderly (50).

The results of Sargent-Cox (2011) showed that the elderly and having more than one medical problem increases the likelihood of self-control in driving (69). Findings from another study suggest that cognitive problems accepted by drivers are associated with worry and avoidance of specific driving situations (70).

Medications: Medications can affect visual, cognitive, or motor abilities while driving (71). Findings from previous studies have shown that taking certain medications, polypharmacy, and even discontinuing some medications can increase the chance of crash in the elderly $(3,2)$.

Medications for treating depression, anxiety, sleep disorders, heart disease, muscle spasms, and medications that affect the CNS can cause problems with safe driving (3, 73). Both prescription and non-prescription drugs can affect the ability to drive (3).

The association between the use of certain drugs such as benzodiazepines, antidepressants, nonsteroidal antiinflammatory, hypnotics, angiotensin-converting enzyme inhibitors, anticoagulants, and lithium drugs, as well as ethanol and drug abuse, has been shown in various studies $(9,72,74)$.

Visual impairments can be caused by taking drugs such as antimalarial, antiarrhythmic, antitubercular agents, antidepressants, anticonvulsants, antianxiety agents, psychotropic, bone disorder agents, musculoskeletal agents, and acne and AIDS-related agents $(75,65)$.

Ethanol and drug abuse, as well as taking drugs with or without prescription, can affect the CNS, affecting attention, Time and distance judgments, searching, and scanning behaviors (65).

Morgan's study concludes that long-term use of highrisk drugs and ethanol and drug abuse are some of the issues to be considered to assess driver competence. He has introduced high-risk drugs for drivers such as Hypnotics, Anticholinergics, Antipsychotics, Benzodiazepines, Opiates, Parkinson medications, Muscle relaxants, Stimulants, Anticonvulsants, Antidepressants (50).

Driving experience: Experience driving and practicing through increased knowledge and driver skill affect driving competence. Having anticipatory abilities helps the driver avoid the dangers (33).

Family concerns about elderly driving or recent driving problems can help identify elderly drivers at risk (76). On the other hand, checking driving records and accidents or errors registered by the police can also be used to predict the driving situation of the elderly.

The elderly can use their experiences to cover deficits created in a particular dimension of their health by taking advantage of other dimensions. For example, people who are not cognitively impaired can drive at a safe speed by understanding their vision problems, adjusting their driving time, driving conditions, environmental conditions, or equipment in their car for safe driving.

\section{Study limitations}

Considering the complexities and problems of acquiring the nature of driving abilities, and in particular examining these abilities in the elderly (with a natural decline in abilities, chronic illnesses, the use of various drugs, and compensating for some disabilities using empirical skills) was one of the limitations of this study. The necessity of using studies whose result is practically usable in our country (e.g., programs that use simulation and web-based applications were excluded) is also one of the most important limitations of this study. The lack of access to some important tools and guidelines in our country due to the lack of access to desired websites. 


\section{Conclusion}

Generally, three key components are needed for safe driving in the elderly, including vision, cognition, and motor function. These factors enable the elderly driver to perform the stages of perception, decision-making, and response correctly. Disorders in any of these abilities, whether caused by the aging process, medical problems, drug use and abuse, fatigue, inattention or distraction, or emotional states, can increase the risk of a crash. However, no single feature or disability can predict the risks associated with elderly driving. The findings of this study can be used by researchers to conduct further studies and police to apply when renewing a driver's license to accurately identify the problems and permanent illnesses caused by the driver's age.

\section{Acknowledgment}

This paper is based on the $\mathrm{PhD}$ thesis of Ms. Saiedeh Bahrampouri supported by the University of Social Welfare and Rehabilitation sciences. Also, Ethical approval was granted by the ethics committee of the University of Social Welfare and Rehabilitation Sciences (IR.USWR.REC.1399.096).

\section{Conflict of Interests}

The authors declare that they have no competing interests.

\section{References}

1. Barusch AS. The Aging Tsunami: Time for a New Metaphor? J Gerontol Soc Work. 2013;56(3):181-4.

2. United Nations, Department of Economic and Social Affairs, Population Division. World Population Prospects 2019, custom data acquired via website. Percentage of total population by broad age group, both sexes (per 100 total population) 2019.

3. NIH's Senior Health: Older Drivers: How Aging Affects Driving: National Institutes of Health; 2012 [cited 2017]. Available from: http://nihseniorhealth.gov/olderdrivers/howagingaffectsdriving/01.htm 1.

4. Levasseur M, Audet T, Gelinas I, Bedard M, Langlais ME, Therrien $\mathrm{FH}$, et al. Awareness tool for safe and responsible driving (OSCAR): a potential educational intervention for increasing interest, openness and knowledge about the abilities required and compensatory strategies among older drivers. Traffic Inj Prev. 2015;16(6):578-86. Epub 2015/03/25

5. Older Adult Drivers G A, USA: Centers for Disease Control and Prevention, National Center for Injury Prevention and Control, Division of Unintentional Injury Prevention; 2015 [updated May 27, 2015].Available

http://www.cdc.gov/motorvehiclesafety/older_adult_drivers/.

6. Older driver statistics Melbourne: Transport Accident Commission(TAC); 2016. Available from: http://www.tac.vic.gov.au/road-safety/statistics/summaries/olderdriver-statistics.

7. Evans L. Risks older drivers face themselves and threats they pose to other road users. Int J Epidemiol. 2000;29(2):315-22.

8. Reichwaldt N, Maslak S, Wolf KH, Haux R. A literature overview and comparison of driving impairing condition assessment approaches by health enabling technologies. Stud Health Technol Inform. 2012;180:1123-5.

9. Moafian G, Aghabeigi MR, Heydari ST, Hoseinzadeh A, Lankarani KB, Sarikhani Y. An epidemiologic survey of road traffic accidents in Iran: analysis of driver-related factors. Chin $\mathrm{J}$ Traumatol. 2013;16(3):140-4.

10. Whelan M, Langford J, Oxley J, Koppel S, Charlton J. The elderly and mobility: A review of the literature. Monash University Accident Research Centre: Report; 2006.
11. Doi Y. A literature review on epidemiologic research on sleep disturbances in the elderly. Nihon Rinsho. 2015;73(6):895-9.

12. European.Commission. Mobility and transport: Assessing the fitness to drive [updated 16/07/2017]. Available from: https://ec.europa.eu/transport/road_safety/specialist/knowledge/old/wh at can be done about it/assessing the fitness to drive en.

13. Dawson JD, Uc EY, Anderson SW, Johnson AM, Rizzo M. Neuropsychological predictors of driving errors in older adults. J Am Geriatr Soc. 2010;58(6):1090-6.

14. Owsley C, Ball K, Sloane ME, Roenker DL, Bruni JR. Visual/cognitive correlates of vehicle accidents in older drivers. Psychol Aging. 1991;6(3):403-15.

15. Marottoli RA, Richardson ED, Stowe MH, Miller EG, Brass LM, Cooney LM Jr, et al. Development of a test battery to identify older drivers at risk for self-reported adverse driving events. J Am Geriatr Soc. 1998;46(5):562-8.

16. McKnight AJ, McKnight AS. Multivariate analysis of age-related driver ability and performance deficits. Accid Anal Prev. 1999;31(5):445-54.

17. De Raedt R, Ponjaert-Kristoffersen I. Short cognitive/neuropsychological test battery for first-tier fitness-to-drive assessment of older adults. Clin Neuropsychol. 2001;15(3):329-36

18. Wang C, Kosinski CJ, Schwartzberg JG, Shanklin AV. Physician's guide to assessing and counseling older drivers: American Medical Association; 2003.

19. Staplin L, Lococo K, Gish KW, Decina LE, TransAnalytics L. Model driver screening and evaluation program. Volume 1, Project summary and model program recommendations. United States. National Highway Traffic Safety Administration, 2003.

20. Kantor B, Mauger L, Richardson VE, Unroe KT. An analysis of an older driver evaluation program. J Am Geriatr Soc. 2004;52(8):132630 .

21. Anstey KJ, Wood J, Lord S, Walker JG. Cognitive, sensory and physical factors enabling driving safety in older adults. Clin Psychol Rev. 2005;25(1):45-65.

22. Classen S, Lopez ED. Mixed methods approach explaining process of an older driver safety systematic literature review. Top Geriatr Rehabil. 2006;22(2):99-112.

23. Langford J, Koppel S, Charlton J, Fildes B, Newstead S. A reassessment of older drivers as a road safety risk. IATSS research. 2006;30(1):27-37.

24. Molnar FJ, Marshall SC, Man-Son-Hing M, Wilson KG, Byszewski AM, Stiell I. Acceptability and concurrent validity of measures to predict older driver involvement in motor vehicle crashes: an Emergency Department pilot case-control study. Accid Anal Prev. 2007;39(5):1056-63.

25. Eby DW, Molnar LJ, Shope JT, Dellinger AM. Development and pilot testing of an assessment battery for older drivers. J Safety Res. 2007;38(5):535-43

26. Wood JM, Anstey KJ, Kerr GK, Lacherez PF, Lord S. A multidomain approach for predicting older driver safety under intraffic road conditions. Am Geriatr Soc. 2008;56(6):986-93.

27. Stav WB, Justiss MD, McCarthy DP, Mann WC, Lanford DN. Predictability of clinical assessments for driving performance. J Safety Res. 2008;39(1):1-7.

28. Edwards JD, Leonard KM, Lunsman M, Dodson J, Bradley S, Myers $\mathrm{CA}$, et al. Acceptability and validity of older driver screening with the DrivingHealth Inventory. Accid Anal Prev. 2008;40(3):1157-63.

29. Classen S, Horgas A, Awadzi K, Messinger-Rapport B, Shechtman $\mathrm{O}$, Joo Y. Clinical predictors of older driver performance on a standardized road test. Traffic Inj Prev. 2008;9(5):456-62.

30. Zook NA, Bennett TL, Lane M. Identifying at-risk older adult community-dwelling drivers through neuropsychological evaluation Appl Neuropsychol. 2009;16(4):281-7.

31. Dobbs BM, Schopflocher D. The Introduction of a New Screening Tool for the Identification of Cognitively Impaired Medically At-Risk Drivers: The SIMARD A Modification of the DemTect. J Prim Care Community Health. 2010;1(2):119-27.

32. American.Medical.Association. US Department of Transportation, and National Highway Traffic Safety Administration. Physician's guide to assessing and counseling older drivers. Washington (DC): National Highway Traffic Safety Administration, 2003. 2010.

33. Lindstrom-Forneri W, Tuokko HA, Garrett D, Molnar F. Driving as an everyday competence: A model of driving competence and behavior. Clin Gerontol. 2010;33(4):283-97. 
34. O'Connor MG, Kapust LR, Lin B, Hollis AM, Jones RN. The 4Cs (crash history, family concerns, clinical condition, and cognitive functions): a screening tool for the evaluation of the at-risk driver. J Am Geriatr Soc. 2010;58(6):1104-8.

35. Munro CA, Jefferys J, Gower EW, Munoz BE, Lyketsos CG, Keay $\mathrm{L}$, et al. Predictors of lane-change errors in older drivers. J Am Geriatr Soc. 2010;58(3):457-64.

36. Betz ME, Schwartz R, Haukoos JS, DiGuiseppi C, Valley M, Johnson R, et al. A pilot study to develop a brief question-based screening tool to identify higher-risk older drivers. J Am Geriatr Soc. 2012;60(9):1791-4.

37. Antin JF, Lockhart TE, Stanley LM, Guo F. Comparing the impairment profiles of older drivers and non-drivers: toward the development of a fitness-to-drive model. Saf Sci. 2012;50(2):333-41.

38. Anstey KJ, Horswill MS, Wood JM, Hatherly C. The role of cognitive and visual abilities as predictors in the Multifactorial Model of Driving Safety. Accid Anal Prev. 2012;45:766-74.

39. Anderson SW, Aksan N, Dawson JD, Uc EY, Johnson AM, Rizzo M. Neuropsychological assessment of driving safety risk in older adults with and without neurologic disease. J Clin Exp Neuropsychol. 2012;34(9):895-905

40. Unsworth CA, Baker A, Taitz C, Chan SP, Pallant JF, Russell KJ, et al. Development of a standardised Occupational Therapy--Driver OffRoad Assessment Battery to assess older and/or functionally impaired drivers. Aust Occup Ther J. 2012;59(1):23-36.

41. Chaudhary NK, Ledingham KA, Eby DW, Molnar LJ. Evaluating older drivers' skills. Preusser Research Group, Inc., 2013.

42. Bowers AR, Anastasio RJ, Sheldon SS, O'Connor MG, Hollis AM, Howe PD, et al. Can we improve clinical prediction of at-risk older drivers? Accid Anal Prev. 2013;59:537-47.

43. Thomas FD, Blomberg RD, Knodler MA, Romoser MR. Licensing procedures for older drivers. United States. National Highway Traffic Safety Administration, 2013.

44. Eramudugolla R, Anstey KJ. Translation of a validated driver screening tool for clinical assessment and research use. NRMA-ACT Road Safety Trust Reports, http://roadsafetytrust org au/c/rtt. 2014

45. Morris JN, Howard EP, Fries BE, Berkowitz R, Goldman B, David D. Using the community health assessment to screen for continued driving. Accid Anal Prev. 2014;63:104-10.

46. Society AG. Clinician's Guide to Assessing and Counseling Older Drivers: US Department of Transportation, National Highway Traffic Safety Administration; 2016.

47. Austroads, National.Transport.Commission(NTC). Assessing fitness to drive for commercial and private vehicle drivers: Medical standards for licensing and clinical management guidelines. Sydney: Austroads Ltd; 2016.

48. Canadian Medical Association. Determining medical fitness to operate motor vehicles. 9 ed: Joule Inc; 2017.

49. Urlings JHJ, Cuenen A, Brijs T, Lutin M, Jongen EMM. Aiding medical professionals in fitness-to-drive screenings for elderly drivers: development of an office-based screening tool. Int Psychogeriatr. 2018;30(8):1211-25.

50. Morgan E. Driving Dilemmas: A Guide to Driving Assessment in Primary Care. Clin Geriatr Med. 2018;34(1):107-15.

51. Ghasemi M, Hoseini Yazdi SH, Heravian J, Jafarzadehpur E, Rezaee M. Comparison of visual status of Iranian military and commercial drivers. Iran Red Crescent Med J. 2015;17(4):e19751.

52. Wheatley CJ, Di Stefano M. Individualized assessment of driving fitness for older individuals with health, disability, and age-related concerns. Traffic Inj Prev. 2008;9(4):320-7.

53. Karthaus M, Falkenstein $M$. Functional Changes and Driving Performance in Older Drivers: Assessment and Interventions. Geriatrics (Basel). 2016;1(2).

54. Tham YC, Li X, Wong TY, Quigley HA, Aung T, Cheng CY. Global prevalence of glaucoma and projections of glaucoma burden through 2040: a systematic review and meta-analysis. Ophthalmology. 2014;121(11):2081-90.

55. Harada CN, Natelson Love MC, Triebel KL. Normal cognitive aging. Clin Geriatr Med. 2013;29(4):737-52.

56. Anstey KJ, Wood J. Chronological age and age-related cognitive deficits are associated with an increase in multiple types of driving errors in late life. Neuropsychology. 2011;25(5):613-21.

57. Racheva R, Totkova Z. Reliability and Validity of a Method for Assessment of Executive Functions in Drivers. Behav Sci (Basel). 2020;10(1).
58. Asimakopulos J, Boychuck Z, Sondergaard D, Poulin V, Menard I, Korner-Bitensky N. Assessing executive function in relation to fitness to drive: a review of tools and their ability to predict safe driving. Aust Occup Ther J. 2012;59(6):402-27.

59. Gandolfi J. Supporting older driver mobility and effective selfregulation. Royal Automobile Club Foundation for Motoring Ltd. 2020

60. Alonso AC, Peterson MD, Busse AL, Jacob-Filho W, Borges MTA, Serra MM, et al. Muscle strength, postural balance, and cognition are associated with braking time during driving in older adults. Exp Gerontol. 2016;85:13-7.

61. Hahn M, Falkenstein M, Wild-Wall N. Age-related performance differences in compensatory tracking under a dual task condition. Occupational Ergonomics. 2010;9(2):75-86

62. Mature Drivers: Governors Highway Safety Association; [cited 2020]. Available from: https://www.ghsa.org/issues/mature-drivers.

63. Taylor JE, Alpass F, Stephens C, Towers A. Driving anxiety and fear in young older adults in New Zealand. Age Ageing. 2011;40(1):62-6.

64. Bernstein JPK, DeVito A, Calamia M. Associations between emotional symptoms and self-reported aberrant driving behaviors in older adults. Accid Anal Prev. 2019;127:28-34.

65. Lococo K, Tyree R. Module 1: Functional Abilities and Safe Driving: Medscape, LLC; 2010 [cited 2020]. Available from: https://www.medscape.org/viewarticle/725015.

66. Dewar RE, Olson PL, Gerson J. Human factors in traffic safety. Second Edition ed: Lawyers \& Judges Publishing Company; 2007.

67. Unsworth C, Chan S-P. Determining fitness to drive among drivers with Alzheimer's disease or cognitive decline. Br J Occup Ther. 2016;79(2):102-10.

68. Naredo Turrado J, Orriols L, Contrand B, Zins M, Salmi LR, Lafont $\mathrm{S}$, et al. Chronic medical conditions and their association with crash risk and changes in driving habits: a prospective study of the GAZEL cohort. Inj Prev. 2020. doi: 10.1136/injuryprev-2019-043460.

69. Sargent-Cox KA, Windsor T, Walker J, Anstey KJ. Health literacy of older drivers and the importance of health experience for selfregulation of driving behaviour. Accid Anal Prev. 2011;43(3):898-905.

70. Fraade-Blanar LA, Hansen RN, Chan KCG, Sears JM, Thompson HJ, Crane PK, et al. Diagnosed dementia and the risk of motor vehicle crash among older drivers. Accid Anal Prev. 2018;113:47-53.

71. Hetland A, Carr DB. Medications and impaired driving. Annals of pharmacotherapy. 2014;48(4):494-506

72. Rudisill TM, Zhu M, Kelley GA, Pilkerton C, Rudisill BR. Medication use and the risk of motor vehicle collisions among licensed drivers: A systematic review. Accid Anal Prev. 2016;96:255-70. Epub 2016/08/30. doi: 10.1016/j.aap.2016.08.001. PubMed PMID: 27569655; PubMed Central PMCID: PMCPmc5045819.

73. Kerrigan S. Drug Toxicology for Prosecutors: Targeting Hardcore Impaired Drivers: American Prosecutors Research Institute; 2004.

74. Bakhtiyari M, Delpisheh A, Monfared AB, Kazemi-Galougahi MH, Mehmandar MR, Riahi M, et al. The road traffic crashes as a neglected public health concern; an observational study from Iranian population. Traffic Inj Prev. 2015;16(1):36-41.

75. Schlote T, Mielke J, Grüb M, Rohrbach JM, Gelisken F. Pocket atlas of ophthalmology: Thieme; 2006.

76. Meuser TM, Carr DB, Unger EA, Ulfarsson GF. Family reports of medically impaired drivers in Missouri: cognitive concerns and licensing outcomes. Accid Anal Prev. 2015;74:17-23. 
S. Bahrampouri, et al.

\begin{tabular}{|c|c|c|c|c|c|}
\hline No & $\begin{array}{c}\text { Author, Year } \\
\text { and Location of } \\
\text { Study } \\
\end{array}$ & Title of Record & Product Name \& Type & $\begin{array}{c}\text { Outcome } \\
\text { measurement }\end{array}$ & Components \\
\hline 1 & $\begin{array}{l}\text { Owsley-1991 } \\
\text { (USA)(14) }\end{array}$ & $\begin{array}{c}\text { Visual/Cognitive Correlates Of } \\
\text { Vehicle Accidents In Older Driv- } \\
\text { ers }\end{array}$ & $\begin{array}{l}\text { Modeling Visual/Cognitive } \\
\text { Correlates Of Accident Fre- } \\
\text { quency(Model) }\end{array}$ & Accidents & $\begin{array}{l}\text { - Cognitive } \\
\text { - Mental Status }\end{array}$ \\
\hline 2 & $\begin{array}{l}\text { Marottoli-1998 } \\
\text { (USA) (15) }\end{array}$ & $\begin{array}{l}\text { Development Of A Test Battery } \\
\text { To Identify Older Drivers At Risk } \\
\text { For Self-Reported Adverse Driv- } \\
\text { ing Events }\end{array}$ & $\begin{array}{l}\text { Test Battery To Identify Older } \\
\text { Drivers At Risk (Battery) }\end{array}$ & $\begin{array}{l}\text { Self-Report Of A } \\
\text { Crash, Moving } \\
\text { Violation, Being } \\
\text { Stopped By Po-- } \\
\text { lice }\end{array}$ & $\begin{array}{l}\text { - Visual } \\
\text { - Cognitive } \\
\text { - Physical }\end{array}$ \\
\hline 3 & $\begin{array}{l}\text { Mcknight-1999 } \\
\text { (USA) (16) }\end{array}$ & $\begin{array}{l}\text { Multivariate analysis of age- } \\
\text { related driver ability and perfor- } \\
\text { mance deficits }\end{array}$ & $\begin{array}{l}\text { Automated Psychophysical } \\
\text { Test (APT) (Predictor Factors) }\end{array}$ & Accidents & $\begin{array}{l}\text { - Sensory } \\
\text { - Cognitive } \\
\text { - Psychomotor } \\
\text { - Perceptual }\end{array}$ \\
\hline 4 & $\begin{array}{l}\text { De Raedt-2001 } \\
\text { (Belgium) (17) }\end{array}$ & $\begin{array}{l}\text { Short Cognitive/ Neuropsycholog- } \\
\text { ical Test Battery For First-Tier } \\
\text { Fitness-To-Drive Assessment Of } \\
\text { Older Adults }\end{array}$ & $\begin{array}{l}\text { Short Cognitive/ Neuropsy- } \\
\text { chological Test Battery }\end{array}$ & $\begin{array}{l}\text { On-The-Road } \\
\text { Driving Test }\end{array}$ & $\begin{array}{c}\text { - Sensory } \\
- \text { Cognitive } \\
\text { - Neuropsychological Test }\end{array}$ \\
\hline 5 & $\begin{array}{l}\text { Wang 2003/ } \\
\text { AMA(USA) } \\
\quad(18)\end{array}$ & $\begin{array}{c}\text { Physician's Guide To } \\
\text { Assessing And Counseling Older } \\
\text { Drivers }\end{array}$ & $\begin{array}{c}\text { Assessment Of } \\
\text { Driving-Related } \\
\text { Skills (ADRes) (Screening } \\
\text { Tool) }\end{array}$ & - & $\begin{array}{l}\text { - Motor } \\
\text { - Cognition } \\
\text { - Vision }\end{array}$ \\
\hline 6 & $\begin{array}{c}\text { Staplin-2003 } \\
\text { NHTSA (USA) } \\
\text { (19) }\end{array}$ & $\begin{array}{l}\text { Model Driver Screening And } \\
\text { Evaluation Program }\end{array}$ & $\begin{array}{l}\text { Driver Screening And Evalua- } \\
\text { tion Program (Model) }\end{array}$ & - & $\begin{array}{l}\text { - Vision } \\
\text { - Mental Functions } \\
\text { - Physical Ability }\end{array}$ \\
\hline 7 & $\begin{array}{l}\text { Kantor-2004 } \\
\text { (USA) (20) }\end{array}$ & $\begin{array}{c}\text { An Analysis Of An Older Driver } \\
\text { Evaluation Program }\end{array}$ & $\begin{array}{l}\text { Model For Predicting On The- } \\
\text { Road Performance(Model) }\end{array}$ & $\begin{array}{l}\text { On-The-Road } \\
\text { Driving Test }\end{array}$ & $\begin{array}{c}- \text { Cognitive } \\
- \text { Functional Status }\end{array}$ \\
\hline 8 & $\begin{array}{l}\text { Anstey-2005 } \\
\text { (AUS) (21) }\end{array}$ & $\begin{array}{l}\text { Cognitive, Sensory And Physical } \\
\text { Factors Enabling Driving Safety } \\
\text { In Older Adults }\end{array}$ & $\begin{array}{l}\text { Model Of Factors Enabling } \\
\text { Safe Driving Behavior(Model) }\end{array}$ & $\begin{array}{l}\text { On-The-Road } \\
\text { Driving Test \& } \\
\text { Accidents }\end{array}$ & $\begin{array}{c}\text { - Cognition } \\
\text { - Sensory Function } \\
\text { - Physical /Medical Function }\end{array}$ \\
\hline 9 & $\begin{array}{l}\text { Classen-2006 } \\
\text { (USA) (22) }\end{array}$ & $\begin{array}{l}\text { Mixed Methods Approach Ex- } \\
\text { plaining Process Of An Older } \\
\text { Driver Safety Systematic Litera- } \\
\text { ture Review }\end{array}$ & $\begin{array}{l}\text { Structural Model For Older } \\
\text { Driver Safety (Model) }\end{array}$ & - & $\begin{array}{l}\text { - Body Function \& Structure } \\
\text { - Medication Use } \\
\text { - Demographics } \\
\text { - Activities } \\
\text { - Exposure Rate }\end{array}$ \\
\hline 10 & $\begin{array}{l}\text { Langford-2006 } \\
\text { (Australia) (23) }\end{array}$ & $\begin{array}{l}\text { A Re-Assessment Of Older Driv- } \\
\text { ers As A Road Safety Risk }\end{array}$ & $\begin{array}{l}\text { Re-Assessment Of Older } \\
\text { Drivers As A Road Safety } \\
\text { (Battery) }\end{array}$ & $\begin{array}{l}\text { On-The-Road } \\
\text { Driving Test }\end{array}$ & $\begin{array}{l}\text { - Vision } \\
\text { - Cognition } \\
\text { - Motor }\end{array}$ \\
\hline 11 & $\begin{array}{l}\text { Molnar- } 2007 \\
\text { (Canada) }(24)\end{array}$ & $\begin{array}{l}\text { Acceptability And Concurrent } \\
\text { Validity Of Measures To Predict } \\
\text { Older Driver Involvement In } \\
\text { Motor Vehicle Crashes }\end{array}$ & $\begin{array}{l}\text { Predicting Measures For Older } \\
\text { Driver Involvement In Motor } \\
\text { Vehicle Crashes (Battery) }\end{array}$ & Accidents & $\begin{array}{c}\text { - Cognitive } \\
\text { - Physical Examination Tests } \\
\text { - Diabetes Mellitus } \\
\text { - Driving Habits Questionnaire } \\
\text { - MMSE }\end{array}$ \\
\hline
\end{tabular}


Components of elder driver competencies

\begin{tabular}{|c|c|c|c|c|c|}
\hline No & $\begin{array}{l}\text { Author, Year and } \\
\text { Location of } \\
\text { Study }\end{array}$ & Title of Record & Product Name \& Type & $\begin{array}{c}\text { Outcome } \\
\text { measurement }\end{array}$ & Components \\
\hline 12 & $\begin{array}{c}\text { Eby-2007 } \\
\text { (USA) (25) }\end{array}$ & $\begin{array}{l}\text { Development And Pilot Testing Of An Assess- } \\
\text { ment Battery For Older Drivers }\end{array}$ & $\begin{array}{l}\text { Comprehensive Battery Of } \\
\text { Assessment Instruments For } \\
\text { Older Drivers (Battery) }\end{array}$ & $\begin{array}{l}\text { Driving Perfor- } \\
\text { mance Or Crash } \\
\text { Risk }\end{array}$ & $\begin{array}{c}\text { - Vision } \\
\text { - Motor } \\
\text { - Cognition } \\
\text { - Driving Behaviors } \\
\text { - Health Questionnaire } \\
\text { - Driving Question- } \\
\text { naire }\end{array}$ \\
\hline 13 & $\begin{array}{l}\text { Wood-2008 } \\
\text { (AUS) (26) }\end{array}$ & $\begin{array}{l}\text { A Multi domain Approach for Predicting Older } \\
\text { Driver Safety Under In-Traffic Road Conditions }\end{array}$ & Multi domain Tests (Battery) & $\begin{array}{l}\text { On-The-Road } \\
\text { Driving Test }\end{array}$ & $\begin{array}{l}\text { - Vision } \\
\text { - Motor } \\
\text { - Cognition }\end{array}$ \\
\hline 14 & $\begin{array}{l}\text { Stav-2008 } \\
\text { (USA) (27) }\end{array}$ & $\begin{array}{l}\text { Predictability Of Clinical Assessments For Driv- } \\
\text { ing Performance }\end{array}$ & Predictive Model (Model) & $\begin{array}{l}\text { On-The-Road } \\
\text { Driving Test }\end{array}$ & $\begin{array}{c}\text { - Vision } \\
\text { - Cognition } \\
\text { - Motor Performance }\end{array}$ \\
\hline 15 & $\begin{array}{l}\text { Edwards-2008 } \\
\text { (USA) (28) }\end{array}$ & $\begin{array}{l}\text { Acceptability And Validity Of Older Driver } \\
\text { Screening WithThe Driving health } ® \text { Inventory }\end{array}$ & $\begin{array}{c}\text { Driver Health } \\
\text { Inventory(DHI) (Battery) }\end{array}$ & Accidents & $\begin{array}{l}\text { - Sensory } \\
\text { - Physical } \\
\text { - Cognitive }\end{array}$ \\
\hline 16 & $\begin{array}{l}\text { Classen-2008 } \\
\text { (USA) }(29)\end{array}$ & $\begin{array}{c}\text { Clinical Predictors Of Older Driver Performance } \\
\text { On A Standardized Road Test }\end{array}$ & $\begin{array}{c}\text { Clinical Predictors Of Older } \\
\text { Driver Performance (Predictor } \\
\text { Factors) }\end{array}$ & $\begin{array}{l}\text { On-The-Road } \\
\text { Driving Test }\end{array}$ & $\begin{array}{l}\text { - Musculoskeletal } \\
\text { Disorder } \\
\text { - Neurological Drug } \\
\text { Treatment Agents } \\
\text { - Cognition }\end{array}$ \\
\hline 17 & $\begin{array}{l}\text { Zook Et Al-2009 } \\
\text { (USA) (30) }\end{array}$ & $\begin{array}{c}\text { Identifying At-Risk Older Adult Community- } \\
\text { Dwelling Drivers Through Neuropsychological } \\
\text { Evaluation }\end{array}$ & $\begin{array}{l}\text { Neuropsychological Tests For } \\
\text { Identifying At-Risk Older } \\
\text { Drivers (Battery) }\end{array}$ & $\begin{array}{l}\text { On-The-Road } \\
\text { Driving Test }\end{array}$ & - Cognitive \\
\hline 18 & $\begin{array}{l}\text { Dobbs }-2010 \\
(\text { Canada })(31)\end{array}$ & $\begin{array}{l}\text { The Introduction of a New Screening Tool for } \\
\text { the Identification of Cognitively Impaired Medi- } \\
\text { cally At-Risk Drivers: The SIMARD A Modifi- } \\
\text { cation of the DemTect }\end{array}$ & DriveAble (Battery) & - & $\begin{array}{c}\text { - Cognitive } \\
\text { - Standardized On- } \\
\text { Road Driving Assess- } \\
\text { ment } \\
\text { - Medical Conditions } \\
\text { - Medications }\end{array}$ \\
\hline 19 & $\begin{array}{l}\text { AMA-2010 } \\
\text { (USA) (32) }\end{array}$ & $\begin{array}{c}\text { Physician's Guide To } \\
\text { Assessing And Counseling Older Drivers }\end{array}$ & $\begin{array}{l}\text { Physician's Guide To } \\
\text { Assessing And Counseling } \\
\text { Older Drivers (Guideline) }\end{array}$ & - & $\begin{array}{c}\text { - Initial Screen } \\
\text { - Assess Driving Re- } \\
\text { lated Skills (ADRES) } \\
\text { - Medical History } \\
\text { - Review Of Systems } \\
\text { - Medications }\end{array}$ \\
\hline 20 & $\begin{array}{l}\text { Lindstrom-2010 } \\
\text { (Canada) (33) }\end{array}$ & $\begin{array}{l}\text { Driving As An Everyday Competence: A Model } \\
\text { Of Driving Competence And Behavior }\end{array}$ & $\begin{array}{l}\text { Driving As An Everyday } \\
\text { Competence (Dec) Model } \\
\text { (Model) }\end{array}$ & - & $\begin{array}{c}\text { - Physical Factors } \\
\text { - Cognitive Factors } \\
\text { - Emotional Factors } \\
\text { - Sensory Factors } \\
\text { - Driving Experience } \\
\text { And Training }\end{array}$ \\
\hline 21 & $\begin{array}{l}\text { O’Connor-2010 } \\
\text { (USA) (34) }\end{array}$ & $\begin{array}{c}\text { The 4Cs (Crash History, Family Concerns, Clin- } \\
\text { ical Condition, And Cognitive Functions): A } \\
\text { Screening Tool For The Evaluation Of The At- } \\
\text { Risk Driver }\end{array}$ & 4Cs Scores (Screening Tool) & $\begin{array}{l}\text { On-The-Road } \\
\text { Driving Test }\end{array}$ & $\begin{array}{l}\text { - Crash History } \\
\text { - Family Concerns } \\
\text { - Medical History } \\
\text { - Cognitive Function }\end{array}$ \\
\hline
\end{tabular}


S. Bahrampouri, et al.

\begin{tabular}{|c|c|c|c|c|c|}
\hline No & $\begin{array}{l}\text { Author, Year and } \\
\text { Location of Study }\end{array}$ & Title of Record & Product Name \& Type & $\begin{array}{c}\text { Outcome } \\
\text { measurement }\end{array}$ & Components \\
\hline 22 & $\begin{array}{c}\text { Munro-2010 } \\
\text { (USA) (35) }\end{array}$ & $\begin{array}{l}\text { Predictors Of Lane-Change Errors } \\
\text { In Older Drivers }\end{array}$ & $\begin{array}{l}\text { Predictors Of Lane-Change } \\
\text { Errors (Predictor Factors) }\end{array}$ & $\begin{array}{l}\text { Lane- } \\
\text { Change } \\
\text { Errors }\end{array}$ & - Cognitive Variables \\
\hline 23 & $\begin{array}{l}\text { Dawson-2010 } \\
\text { (USA) (13) }\end{array}$ & $\begin{array}{l}\text { Neuropsychological Predictors Of } \\
\text { Driving Errors In Older Adults }\end{array}$ & $\begin{array}{l}\text { Off-Road Neuropsychological } \\
\text { Battery (Predictor Factors) }\end{array}$ & $\begin{array}{l}\text { Driving } \\
\text { Error }\end{array}$ & $\begin{array}{c}\text { - Cognitive Abilities } \\
\text { - Vision } \\
\text { - Motor Skills }\end{array}$ \\
\hline 24 & $\begin{array}{l}\text { Betz-2012 } \\
(\text { USA) }(36)\end{array}$ & $\begin{array}{c}\text { A Pilot Study To Develop A Brief } \\
\text { Question-Based Screening Tool } \\
\text { To Identify Higher-Risk Older } \\
\text { Drivers }\end{array}$ & CRASH (Screening Tool) & $\begin{array}{l}\text { Crashes Or } \\
\text { Police Stops }\end{array}$ & $\begin{array}{c}\text { - Feel Confused Or Disori- } \\
\text { ented While Driving } \\
\text { - Driver Avoid Driving } \\
\text { Alone } \\
\text { - Difficulty Seeing } \\
\text { - Hand Over The Keys }\end{array}$ \\
\hline 25 & $\begin{array}{l}\text { Antin-2012 } \\
\text { (USA) (37) }\end{array}$ & $\begin{array}{l}\text { Comparing the impairment pro- } \\
\text { files of older drivers and non- } \\
\text { drivers: Toward } \\
\text { the development of a fitness-to- } \\
\text { drive model }\end{array}$ & a fitness-to-drive model (Model) & - & $\begin{array}{c}\text { - Perception } \\
\text { - Physical Ability } \\
\text { - Visual } \\
\text { - Cognitive Ability }\end{array}$ \\
\hline 26 & $\begin{array}{l}\text { Anstey-2012 } \\
\text { (AUS) (38) }\end{array}$ & $\begin{array}{c}\text { The Role Of Cognitive And Visual } \\
\text { Abilities As Predictors In The } \\
\text { Multifactorial Model } \\
\text { Of Driving Safety }\end{array}$ & $\begin{array}{c}\text { Multifactorial } \\
\text { Model Of Driving Safety (Mod- } \\
\text { el) }\end{array}$ & $\begin{array}{l}\text { Capacity To } \\
\text { Drive Safe- } \\
\text { ly, Hazard } \\
\text { Change } \\
\text { Detection } \\
\text { Task }\end{array}$ & $\begin{array}{c}\text { - Visual } \\
- \text { Cognitive } \\
\text { - Capacity To Drive Safely }\end{array}$ \\
\hline 27 & $\begin{array}{l}\text { Anderson-2012 } \\
\text { (USA) (39) }\end{array}$ & $\begin{array}{c}\text { Neuropsychological Assessment } \\
\text { Of Driving Safety Risk In Older } \\
\text { Adults With And Without Neuro- } \\
\text { logic Disease }\end{array}$ & (Battery) & $\begin{array}{l}\text { On-The- } \\
\text { Road Driv- } \\
\text { ing Test }\end{array}$ & $\begin{array}{c}\text { - Visual Sensory Functioning } \\
\text { - Neuropsychological Tests } \\
\text { - Road Test }\end{array}$ \\
\hline 28 & $\begin{array}{l}\text { Unsworth-2012 } \\
\text { (AUS) (40) }\end{array}$ & $\begin{array}{l}\text { Development of a Standardised } \\
\text { Occupational Therapy - Driver } \\
\text { Off-Road Assessment Battery To } \\
\text { Assess Older and/ or Functionally } \\
\text { Impaired Drivers }\end{array}$ & OT-DORA (Battery) & Cart Model & $\begin{array}{c}\text { - Initial Interview } \\
\text { - Sensory Assessment } \\
\text { - Cognitive Assessment } \\
\text { - Physical Assessment } \\
\text { - Medical History } \\
\text { - Medication Screen }\end{array}$ \\
\hline 29 & $\begin{array}{l}\text { Chaudhary- } \\
\text { NHTSA } 2013 \\
\text { (USA) }(41)\end{array}$ & Evaluating Older Drivers' Skills & $\begin{array}{c}\text { Evaluating Older } \\
\text { Drivers' Skills (Guideline) }\end{array}$ & - & $\begin{array}{l}\text { - Cognitive } \\
\text { - Motor } \\
\text { - Vision }\end{array}$ \\
\hline 30 & $\begin{array}{l}\text { Bowers-2013 } \\
\text { (USA) (42) }\end{array}$ & $\begin{array}{l}\text { Can We Improve Clinical Predic- } \\
\text { tion Of At-Risk Older Drivers? }\end{array}$ & $\begin{array}{c}\text { Clinical Prediction Of At-Risk } \\
\text { Older Drivers (Predictor Fac- } \\
\text { tors) }\end{array}$ & $\begin{array}{l}\text { On-The- } \\
\text { Road Driv- } \\
\text { ing Test }\end{array}$ & $\begin{array}{l}\text { - Cognitive } \\
\text { - Vision }\end{array}$ \\
\hline 31 & $\begin{array}{l}\text { Thomas-2013 } \\
\text { (USA) (43) }\end{array}$ & $\begin{array}{c}\text { Licensing Procedures For Older } \\
\text { Drivers }\end{array}$ & (Guideline) & - & $\begin{array}{c}\text { - Cognitive } \\
\text { - Visual Perceptual } \\
\text { - Psychomotor And Mobility }\end{array}$ \\
\hline
\end{tabular}




\begin{tabular}{|c|c|c|c|c|c|}
\hline \multicolumn{6}{|c|}{ Appendix. Ctd } \\
\hline No & $\begin{array}{l}\text { Author, Year and } \\
\text { Location of Study }\end{array}$ & Title of Record & Product Name \& Type & $\begin{array}{c}\text { Outcome } \\
\text { measurement }\end{array}$ & Components \\
\hline 32 & $\begin{array}{l}\text { Eramudugolla - } \\
2013 \\
\text { (AUS) (44) }\end{array}$ & $\begin{array}{c}\text { The Multi-D } \\
\text { Driver Screening Battery }\end{array}$ & Multi-D (Battery) & $\begin{array}{l}\text { On-Road } \\
\text { Errors }\end{array}$ & $\begin{array}{l}\text { - Cognitive } \\
\text { - Motor } \\
\text { - Sensory }\end{array}$ \\
\hline 33 & $\begin{array}{l}\text { Morris-2014 } \\
\text { (USA) (45) }\end{array}$ & $\begin{array}{l}\text { Using The Community Health } \\
\text { Assessment To Screen For Con- } \\
\text { tinued Driving }\end{array}$ & $\begin{array}{l}\text { Driving Review Index (DRI) } \\
\text { (Screening Tool) }\end{array}$ & $\begin{array}{l}\text { Driving } \\
\text { Behavior }\end{array}$ & $\begin{array}{l}\text { - Cognitive Measures } \\
\text { - Functional Measures } \\
\text { - Clinical/Health Frailty }\end{array}$ \\
\hline 34 & $\begin{array}{l}\text { NHTSA-2016 } \\
\text { (USA) }(46)\end{array}$ & $\begin{array}{l}\text { Clinician's Guide To Assessing } \\
\text { And Counseling Older Drivers }\end{array}$ & $\begin{array}{c}\text { Clinical Assessment Of Driving } \\
\text { Related Skills (CADRES) } \\
\text { (Screening Tool) }\end{array}$ & - & $\begin{array}{c}\text { - General } \\
\text { - Vision } \\
\text { - Cognition } \\
\text { - Motor/Sensory }\end{array}$ \\
\hline 35 & $\begin{array}{l}\text { Austroads-2016 } \\
\text { (AUS) (47) }\end{array}$ & Assessing Fitness To Drive & $\begin{array}{l}\text { Assessing Fitness To Drive } \\
\text { (Guideline) }\end{array}$ & - & $\begin{array}{c}\text { - Sensory } \\
\text { - Cognitive } \\
\text { - Motor } \\
\text { - Drugs } \\
\text { - Conditions Likely To Af- } \\
\text { fect Driving } \\
\text { - Medical Conditions }\end{array}$ \\
\hline 36 & $\begin{array}{l}\text { CMA Driver's } \\
\text { Guide- } 2017 \\
\text { (Canada) }(48)\end{array}$ & $\begin{array}{l}\text { Determining } \\
\text { Medical Fitness } \\
\text { To Operate } \\
\text { Motor Vehicles }\end{array}$ & (Guideline) & - & $\begin{array}{c}\text { - Red Flags } \\
\text { - Hidden Disease } \\
\text { - Cognition } \\
\text { - Drugs } \\
\text { - Record } \\
\text { - In-Car Experiences } \\
\text { - Vision } \\
\text { - Ethanol Use } \\
\text { - Multiple Comorbidities }\end{array}$ \\
\hline 37 & $\begin{array}{l}\text { Urlings-2018 } \\
\text { (Belgium) (49) }\end{array}$ & $\begin{array}{l}\text { Aiding Medical Professionals In } \\
\text { Fitness-To-Drive Screenings For } \\
\text { Elderly Drivers: Development Of } \\
\text { An Office-Based Screening Tool }\end{array}$ & $\begin{array}{l}\text { Predictive Battery Of Tests For } \\
\text { Fitness To Drive Screenings } \\
\text { (Screening Tool) }\end{array}$ & $\begin{array}{l}\text { On-The- } \\
\text { Road Driv- } \\
\text { ing Test }\end{array}$ & $\begin{array}{l}\text { - Vision } \\
\text { - Physical } \\
\text { - Cognitive }\end{array}$ \\
\hline
\end{tabular}

